\title{
RANCANG BANGUN SISTEM INFORMASI KONSULTASI DAN PENJADWALAN FISIOTERAPI PENYAKIT BELL'S PALSY (STUDI KASUS KLINIK GRIYA FISIOTERAPIS)
}

\author{
(Development of Information System Bell's Palsy Disease for Consulting and \\ Scheduling (Case Study Griya Physiotherapy Clinic) \\ Rejalana Bayu Kurniawan*, Nadiyasari Agitha, Royana Afwani \\ Dept Informatics Engineering, Mataram University \\ JI. Majapahit 62, Mataram, Lombok NTB, INDONESIA \\ Email: bayupkpr@gmail.com, [nadiya, royana]@unram.ac.id
}

\begin{abstract}
Bell's palsy is an acute paralysis of the primary facial nerve, the cause of which is unknown and causes permanent disability if not treated properly, so that the treatment must be carried out directly by an expert as is done at the Griya Fisioterapis Clinic. The clinic serves the treatment of Bell's Palsy by 1 physiotherapist, but at the clinic there is no medical record data storage so it only uses the memory of a physiotherapist to handle the patient's history. Then for the consultation scheduling of each patient is still used via short messages, so that the schedule for each patient is not well organized. Therefore, a Bell's Palsy Disease Scheduling Consultation Information System was built which can help in overcoming physiotherapy scheduling and medical record recording, so that it can be well controlled and coordinated. The development method in information systems is designed using the RUP (Rational Unified Process) method, where testing using the RUP method is carried out using black box testing and using usability (questionnaire). In black box testing, the result is 1, which means that all features are running well. In the usability test, the results obtained were $92.30 \%$ which was stated relatively feasible because it was carried out on a physiotherapist, and $87.03 \%$ was carried out on 30 respondents who met the usability standard declared "Very Feasible", so the RUP method was a good method for system development.
\end{abstract}

Kata Kunci: Metode Rational Unified Process, RUP, Sistem Informasi, Website, Klink Griya Fisioterapis

*Penulis Korespondensi

\section{Pendahuluan}

Seiring dengan perkembangan teknologi informasi yang semakin pesat di berbagai bidang, pelayanan kesehatan dituntut untuk melakukan perbaikan secara terus menerus untuk dapat meningkatkan kenyamanan, kemudahan dan keamanan bagi pengguna maupun pengelola jasa kesehatan. Salah satu contoh pelayanan kesehatan pada era modern saat ini adalah pelayanan fisioterapi Bell's palsy.

Fisioterapi merupakan proses merehabilitasi seorang agar terhindar dari cacat fisik melalui serangkaian pencegahan, diagnosis dan penanganan gangguan fisik pada tubuh atau penyakit. Sedangkan Bell's palsy merupakan suatu kelumpuhan akut nervus fasialis prifer yang tidak diketahui sebabnya [1]. Di Indonesia, insiden penyakit Bell' palsy banyak terjadi namun secara pasti sulit ditentukan. Dalam hal ini didapatkan frekuensi terjadinya Bell's palsy di Indonesia sebesar 19,55\%, dari seluruh kasus neuropati terbanyak yang sering dijumpai terjadi pada usia 20 - 50 tahun dimana angka kejadian meningkat dengan bertambahnya usia setelah 60 tahun. Maka diperlukannya fisioterapis yang mampu melakukan diagnosis berdasarkan ilmu pengetahuan dan pengalaman yang dimiliki dengan melakukan terapi [2]. Masalah kecacatan yang ditimbulkan oleh Bell's palsy cukup kompleks, yaitu meliputi impairment (kelainan di tingkat organ) berupa ketidak simetrisnya wajah, kaku dan bahkan bisa berakibat terjadi kontraktur, disability atau ketidakmampuan berupa keterbatasan dalam aktivitas sehari-hari berupa gangguan makan dan minum, menutup mata, serta gangguan berbicara dan ekspresi wajah, masalah selanjutnya dari segi kejiwaan penderita [3]. 
Metode pengembangan dalam sistem informasi yang dirancang menggunakan metode RUP (Rational Unified Process). RUP menyediakan pendefinisian yang baik untuk alur hidup proyek perangkat lunak, dimana RUP melakukan pendekatan perangkat lunak secara berulang-ulang (iterative), fokus pada arsitektur, lebih diarahkan berdasarkan pengerjaan perangkat lunak mulai dari pengumpulan awal dan penentuan kebutuhan sampai proses pembuatan program. Penggunaan web juga dilakukan berdasarkan kebutuhan sistem yang memudahkan dalam pengolahan data serta mempermudahkan tanpa harus dialakukannya instalasi sistem. Sehingga cocok untuk perancangan sistem informasi yang akan dibuat dalam penelitian yang diambil [4].

Berdasarkan uraian diatas penulis mengajukan sebuah penelitian dengan judul "Rancang Bangun Sistem Informasi Dan Konsultasi Penjadwalan Fisioterapi Penyakit Bell's Palsy (Studi Kasus Klinik Griya Fisioterapis)", sistem informasi ini diharapkan dapat memberikan informasi konsultasi jadwal fisioterapi sehingga dapat mengatasi permasalahan awal penanganan penyakit Bell's palsy [2].

\section{TinjauAn Pustaka dan DASAR TeORI}

\subsection{Tinjauan Pustaka}

Beberapa penelitian yang terkait dengan rancang bangun sistem informasi dan konsultasi penjadwalan fisioterapi penyakit Bell's palsy sebagai berikut. Penelitian tentang sistem Informasi penjadwalan dokter berbasis web sistem informasi penjadwalan dokter ini diuji dengan menggunakan 3 metode pengujian yaitu whitebox testing, software tester dan blackbox (ISO 9126) dengan melakukan pengujian kuisioner kepada bagian informasi, dokter dan pasien. Hasil dari perhitungan kualitas sistem dihasilkan dengan presentase tanggapan sebesar $87,87 \%$ dengan kriteria perhitungan sistem sangat baik [5].

Penelitian tentang perbandingan antara metode RUP dan Prototype dalam aplikasi penerimaan siswa baru berbasis web bertujuan untuk mengetahui gambaran secara sistematis, faktual dan akurat mengenai fakta-fakta dan sifat-sifat pada suatu objek penelitian tertentu pada pengembangan perangkat lunak. Metode pengembangan perangkat lunak model RUP dirancang agar dapat menerima perubahan dalam rangka menyempurnakan prototype yang sudah ada, sehingga pada akhirnya dapat menghasilkan perangkat lunak yang dapat diterima dan perubahan yang terjadi dapat dianggap bagian dari proses pengembangan itu sendiri [4].
Penelitian tentang karakteristik pasien bell's palsy bertujuan untuk menganalisis karakteristik pasien yang terkena penyakit Bell's palsy dengan subjek terbanyak yang menderita Bell's palsy berada pada kelompok 46 - 55 tahun yaitu sebanyak 11 orang (35,5 \%) dan terendah pada kelompok umur 6 - 10 tahun dan >65 tahun yaitu 0. Dari penelitian ini, didapatkan bahwa subjek terbanyak yang menderita Bell's palsy berada pada kelompok perempuan yaitu sebanyak 19 orang (61,3 \%) dan terendah pada kelompok laki-laki sebanyak 12 orang ( $38,7 \%)$ [1].

Penelitian tentang penatalaksanaan fisioterapi untuk meningkatkan kekuatan otot dan mengembalikan kesimetrisan wajah pada kasus bell's palsy yang bertujuan untuk mempercepat penyembuhan pasien penderita Bell's palsy dengan melakukan terapi secara cepat dan tepat, dimana dilakukan dengan menggunakan modalitas Infra red (IR), massage, Neuro Muscular Taping (NMT), dan mirror exercise serta edukasi untuk kondisi Bell's palsy yang dilaksanakan di RSUD dr.Soeselo Slawi dan dilakukan sebanyak 3 kali terapi dengan nama pasien Tn. D umur 63 tahun diperoleh hasil meningkatnya kekuatan otot-otot wajah, meningkatnya kemampuan fungsional otot-otot wajah seperti saat istirahat, mengerutkan dahi memejamkan mata, serta membantu mempercepat proses kesembuhan pasien pada kondisi bell's palsy [6].

Penelitian tentang penerapan metode Rational Unified Process (RUP) dalam pengembangan sistem informasi medical check up pada Citra Medical Center, menghasilkan akurasi berdasarkan pengujian yang dilakukan dengan menggunakan kuesioner. Pengujian dilakukan oleh 2 orang dari puskesmas dan 30 orang masyarakat dengan hasil yang diperoleh sebesar $86,12 \%$ (sangat layak) sehingga metode RUP sudah baik digunakan [7].

Penelitian tentang sistem informasi konsultasi kesehatan berbasis web bertujuan untuk memberikan pelayanan kesehatan kepada masyarakat umum secara online, dengan menyediakan informasi yang dimuat dalam artikel kesehatan online, pengunjung web pun dapat melakukan konsultasi secara langsung dengan dokter yang terdaftar dalam website. Dengan adanya website ini walaupun sedang dalam kondisi sibuk dimanapun kita berada kita tetap bisa berupaya menjaga kesehatan tubuh dengan membaca artikel kesehatan online dan melakukan konsultasi kesehatan secara rutin [8].

Penelitian tentang rancang bangun sistem informasi konsultasi medis berbasis website bertujuan untuk membantu tempat praktik dokter gigi dan 
memberikan kemudahan konsultasi medis kepada pasien, dimana pada penelitian yang diambil masih menggunakan cara manual dalam pengolahan data yang meliputi penyimpanan data pasien, registrasi pasien, konsultasi medis dan pelayanan informasi, sehingga pengolahan data belum terkomputerisasi dan sistematis sehingga sulit untuk melakukan pencarian data pasien [9].

Berdasarkan penelitian yang pernah dilakukan, penulis bermaksud untuk menggunakan metode pengembangan perangkat lunak model Rational Unified Process (RUP) sebagai pengembangan perangkat lunak yang akan dibangun, dengan studi kasus yang diambil yaitu Klinik Griya Fisioterapis yang bertujuan untuk menghasilkan sistem informasi konsultasi penjadwalan fisioterapis yang sistematis berdasarkan konsultasi awal dan pemeriksaan pakar terkait nilai otot seperti.

Adapun perancangan alur sistem sudah disesuaikan dengan Standard Operating Procedure dari pihak klinik, dimana dilakukan tahapan konsultasi secara langsung antara pasien dengan Fisioterapis dengan gejala yang dialami, kemudian dilakukan pemeriksaan lebih lanjut dengan melakukan pemeriksaan nilai otot, selanjutnya dari hasil pemeriksaan dilakukan diagnosis bahwa pasien mengalami penyakit Bell's palsy dengan tingkatan ringan, sedang, berat sehingga harus dilakukan penjadwalan fisioterapi, hal tersebut digambarkan seperti pada Gambar 1.

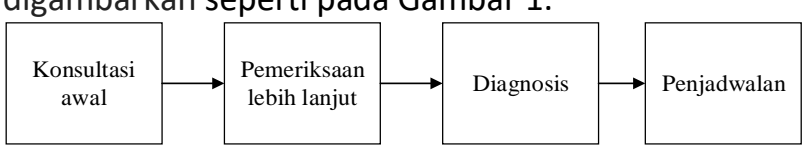

Gambar 1. Alur sistem bekerja

\subsection{Dasar Teori}

Berikut merupakan dasar teori yang berkaitan dengan rancang bangun sistem informasi dan konsultasi penjadwalan fisioterapi penyakit Bell's palsy (studi kasus klinik griya fisioterapis) sebagai berikut:

\subsubsection{Rational Unified Process}

Rational Unified Process (RUP) adalah pendekatan perangkat lunak yang dilakukan berulangulang (iterative), fokus pada arsitektur (architecturecentric), lebih diarahkan berdasarkan penggunaan kasus (use case driven). RUP juga merupakan proses rekayasa perangkat lunak dengan pendefinisian yang lebih baik (well defined) dan penstrukturan yang baik (well structured) [4]. RUP menggunakan konsep object oriented, dengan aktifitas yang berfokus pada pengembangan model dengan menggunakan Unified Model Language (UML). UML mendefinisikan notasi dan syntax, notasi UML merupakan sekumpulan bentuk khusus untuk menggambarkan berbagai diagram piranti lunak [10]. Proses pengulangan/iteratif pada RUP secara global dapat dlihat pada Gambar 2.

RUP memiliki 4 tahap atau fase yang dapat dilakukan pula secara iterative [11]. Berikut adalah penjelasan untuk setiap fase RUP:

a. Inception (permulaan) tahap ini lebih pada memodelkan proses bisnis yang dibutuhkan (business modeling) dan mendefinisikan kebutuhan akan sistem yang akan dibuat (requirements).

b. Elaboration (perluasaan atau perencanaan) tahap ini lebih difokuskan pada perencanaan arsitektur sistem. Tahap ini juga dapat mendeteksi apakah arsitektur sistem yang diinginkan dapat dibuat atau tidak. Mendeteksi resiko yang mungkin terjadi dari arsitektur yang dibuat. Tahap ini lebih pada analisis dan desain sistem serta implementasi sistem yang fokus pada purwarupa sistem (prototype).

c. Contruction (kontruksi) tahap ini fokus pada pengembangan komponen dan fitur-fitur sistem. Tahapan ini lebih pada implementasi dan pengujian sistem yang fokus pada implementasi perangkat lunak pada kode program. Tahap ini menghasilkan produk perangkat lunak dimana menjadi syarat dari Initial Operational Capability Milestone atau batas atau tonggak kemampuan operasional awal.

d. Transition (transisi) tahap ini lebih pada deployment atau instalasi sistem agar dapat dimengerti oleh user. Tahap ini menghasilkan produk perangkat lunak dimana menjadi syarat dari Initial Operational Capability Milestone atau batas atau tonggak kemampuan operasional awal. Aktifitas pada tahap ini termasuk pada pelatihan user, pemeliharaan dan pengujian sistem apakah sudah memenuhi harapan user.

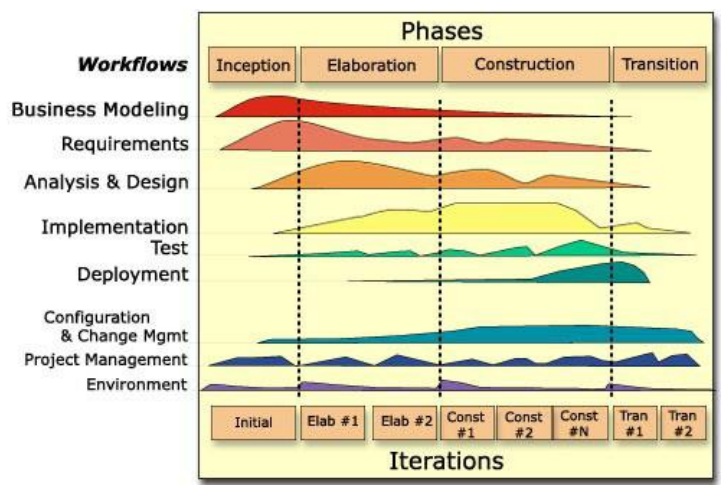

Gambar 2.Proses iterative RUP 


\subsubsection{ISO 25010}

ISO 25010 adalah standar kualitas perangkat lunak yang baru, menggantikan ISO 9126. Pada penelitian ini akan diambil 2 karakteristik ISO 25010 yaitu functional suitability, dan usability [7]:

a. Functional Suitability, dimana pengujian ini menggunakan metode black-box testing. Blackbox testing disebut juga pengujian perilaku, berfokus pada persyaratan fungsionalitas perangkat lunak. Hasil pengujian functional suitability dihitung mengunakan persamaan (1):

$$
\mathrm{X}=\frac{I}{P}
$$

Keterangan:

$\mathrm{P}=$ Jumlah fitur yang dirancang

$\mathrm{I}$ = Jumlah fitur yang berhasil diimplementasi

Dalam pengujian, produk dikatakan baik dalam functional suitability jika nilai $X$ mendekati 1.

b. Usability, merupakan pengujian yang menggunakan kuesioner USE Questionnaire dengan skala likert dan rumus perhitungan skor pengujian usability yaitu:

$$
\begin{aligned}
\text { Skor total }= & (J S S x 5)+(J S x 4)+(J N \times 3)+ \\
& (J T S x<2)+(J S T S x 1)
\end{aligned}
$$

Keterangan:

JSS = jumlah responden menjawab Sangat Setuju

$\mathrm{JS}=$ jumlah responden menjawab Setuju

$\mathrm{JN}=$ jumlah responden menjawab Netral

JTS = jumlah responden menjawab Tidak Setuju

JSTS = jumlah responden menjawab Sangat idak Setuju

Kemudian mencari persentase skor untuk mendapatkan kriteria interpretasi skor hasil pengujian usability dengan rumus persamaan (3):

$P$ skor $=$ Skor total i x r x $5 \times 100 \%$

Keterangan:

Skor total = skor total hasil jawaban responden

i $\quad=$ jumlah pertanyaan

$r \quad=$ jumlah responden

Setelah mendapatkan hasil berupa nilai kuantitatif dari perhitungan sebelumnya, nilai dikonversi menjadi nilai kualitatif berskala 5 dengan skala Likert. Konversi persentase ke pernyataan seperti dalam Tabel I.

TABEL I. KRITERIA INSTERPRESTASI SKOR

\begin{tabular}{|c|c|c|}
\hline No & Presentase Pencapaian & Interprestasi \\
\hline 1 & $0 \%-20 \%$ & Sangat Tidak Layak \\
\hline 2 & $21 \%-40 \%$ & Kurang Layak \\
\hline 3 & $41 \%-60 \%$ & Cukup Layak \\
\hline 4 & $61 \%-80 \%$ & Layak \\
\hline 5 & $81 \%-100 \%$ & Sangat Layak \\
\hline
\end{tabular}

\subsubsection{UML}

Unified Modelling Language (UML) adalah sebuah "bahasa" yang telah menjadi standar dalam industri untuk visualisasi, merancang dan mendokumentasikan sistem piranti lunak. UML menawarkan sebuah standar untuk merancang model sebuah sistem. Dengan menggunakan UML kita dapat membuat model untuk semua jenis aplikasi piranti lunak, dimana aplikasi tersebut dapat berjalan pada piranti keras, sistem operasi dan jaringan apapun, serta ditulis dalam bahasa pemrograman apapun. Tetapi karena UML juga menggunakan Class dan operation dalam konsep dasarnya, maka ia lebih cocok untuk penulisan piranti lunak dalam bahasabahasa berorientasi objek seperti $\mathrm{C}++$, Java, C\# atau VB.NET. Walaupun demikian, UML tetap dapat digunakan untuk modeling aplikasi prosedural dalam VB atau C [10].

\subsubsection{MySQL}

MySQL adalah Sebuah program database server yang mampu menerima dan mengirimkan datanya sangat cepat, multi user serta menggunakan perintah dasar SQL (Structured Query Language). MySQL merupakan dua bentuk lisensi, yaitu Free Software dan Shareware. MySQL yang biasa kita gunakan adalah MySQL Free Software yang berada dibawah Lisensi GNU/GPL (General Public License) [12].

\section{Metode Penelitian}

Dalam pengembangan sistem menggunakan beberapa tahapan yang mengikuti metode RUP seperti yang terlihat pada Gambar 3.

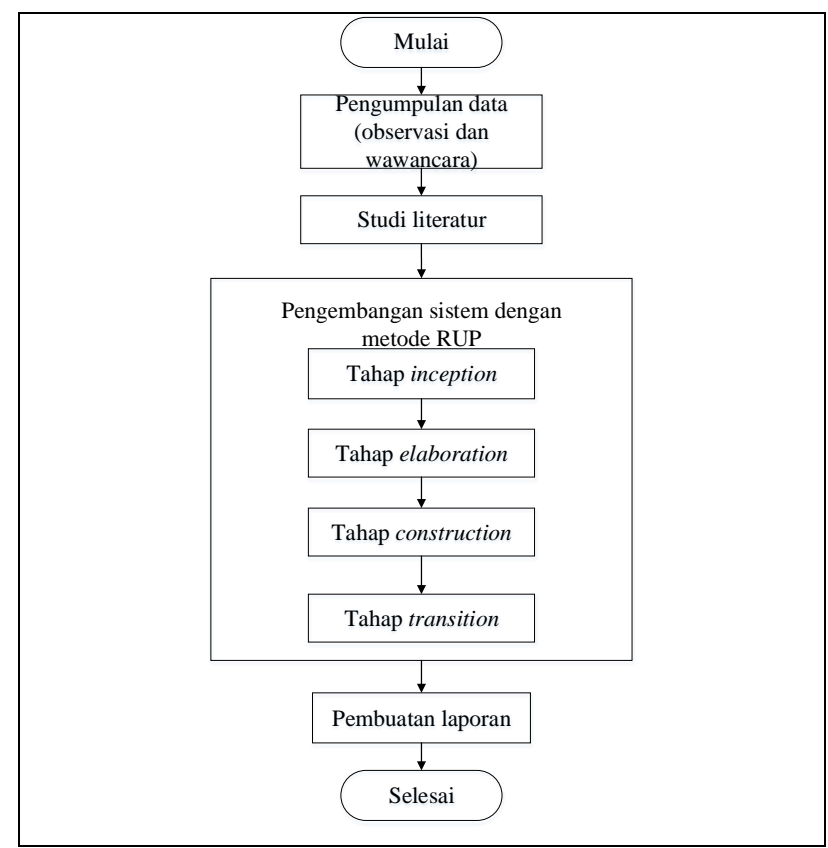

Gambar 3. Tahapan pengembangan sistem 
Berikut merupakan penjelasan mengenai tahapan pengembangan sistem berdasarkan pada Gambar 3.

\subsection{Pengumpulan Data}

Pengumpulan data pada tugas akhir ini dilakukan dengan dua cara yaitu observasi dan wawancara. Pada proses observasi yang dilakukan, penulis mengamati secara langsung bagaimana proses pengelolaan data pasien penyakit Bell's palsy, proses melakukan penjadwalan penyakit Bell's palsy dan evaluasi pasien penyakit Bell's palsy. Hasil yang didapat dari observasi yang dilakukan yaitu sebuah form konsultasi awal dengan analisis status dari fisioterapis. Pada wawancara yang dilakukan penulis di Klinik Griya Fisioterapis dengan Bapak R. Arif Trianto C, S.ST.FT., S.Th.I., NMTCP-SM selaku fisioterpis, dijelaskan mengenai proses penjadwalan fisioterapi penyakit Bell's palsy yang hanya dilakukan menggunakan media sosial yaitu Whatsapp. Dilakukanya studi literatur bertujuan untuk melihat kekurangan serta kelebihan yang ada pada skripsi, jurnal maupun sumber lainnya yang nantinya digunakan sebagai acuan untuk mengembangkan sistem yang akan dibangun.

\subsection{Pengembangan sistem dengan metode RUP}

Pada pengembangan sistem dengan metode RUP terdapat 4 tahapan, yaitu tahap inception, elaboration, construction, dan transition.

\subsubsection{Tahap Inception}

Pada tahap inception dilakukan 4 proses perancangan yang dilakukan yaitu business modelling, requirement, analysis and design inception, dan test inception.

a. Business Modelling, pada bussines modelling canvas yang digunakan pada tahap awal untuk memulai perancangan sistem seperti pada Gambar 4.

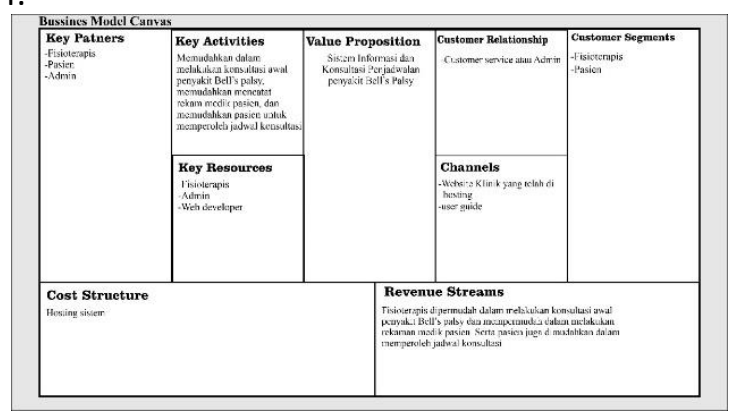

Gambar 4. Business modelling canvas

b. Requirement, kebutuhan sistem dibedakan menjadi kebutuhan fungsional dan non fungsional. Masing-masing aktor memiliki hak akses yang berbeda seperti yang terlihat pada TABEL II.
TABEL II. KEBUTUHAN FUNGSIOANAL SISTEM

\begin{tabular}{|c|c|c|}
\hline No & Kebutuhan Fungsional & Aktor \\
\hline 1 & Menambah data pasien & \multirow[t]{9}{*}{ Admin } \\
\hline 2 & Mengubah data pasien & \\
\hline 3 & Menghapus data pasien & \\
\hline 4 & Mencetak rekam medik & \\
\hline 5 & Melihat grafik pasien & \\
\hline 6 & Menambah jadwal fisioterapi & \\
\hline 7 & Mengubah jadwal fisioterapi & \\
\hline 8 & Menghapus jadwal fisioterapi & \\
\hline 9 & Melihat jadwal fisioterapi & \\
\hline 10 & Melihat grafik pasien & \multirow[t]{4}{*}{ Fisioterapis } \\
\hline 11 & Melihat rekam medik & \\
\hline 12 & Melihat jadwal fisioterapi & \\
\hline 13 & Menambah rekam medik & \\
\hline 14 & Melihat jadwal & Pasien \\
\hline
\end{tabular}

c. Analysis and Design Inception, pada tahap ini dijelaskan dengan menggunakan use case diagram, dimana use case diagram mendeskripsikan interaksi tipikal antara para pengguna sistem dengan sistem itu sendiri, dengan memberikan sebuah narasi tentang bagaimana sistem tersebut digunakan [13]. Use case diagram ini dapat dilihat pada Gambar 5.

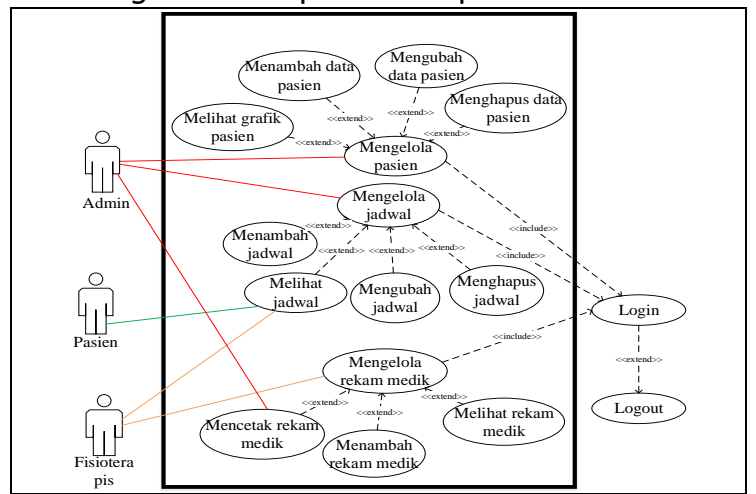

Gambar 5. Use case diagram sistem

Berdasarkan Gambar 5 diketahui bahwa pada sistem ini terdapat 3 aktor yang berperan sebagai Admin, Fisioterapis dan Pasien, dimana masingmasing aktor memiliki akses yang berbeda-beda. Admin memiliki 9 akses, Fisioterapis memiliki akses 3 akses dan Pasien memiliki 1 akses yaitu dapat melihat jadwal. Semua akses yang diberikan dapat dilakukan dengan melakukan login ke sistem.

d. Test Inception, pada tahap ini pengujian bertujuan untuk melakukan validasi kebutuhan sistem berdasarakan use case yang telah dirancang. Pengujian melibatkan pakar fisioterapis Klinik Griya Fisioterapis dimana pengujian dilakukan dengan mencocokkan use case berdasarkan kebutuhan fungsional sistem. 
TABEL III. Validasi KeSESUAIAN USE CASE DENGAN KEBUTUHAN SISTEM

\begin{tabular}{|c|l|c|c|c|}
\hline \multirow{2}{*}{ No } & \multicolumn{1}{|c|}{$\begin{array}{c}\text { Kebutuhan fungsional } \\
\text { sistem }\end{array}$} & \multicolumn{3}{c|}{ Use Case } \\
\cline { 3 - 5 } 1 & $\begin{array}{l}\text { Mengelola pasien } \\
\text { (menambah, mengubah, } \\
\text { dan menghapus) }\end{array}$ & $\checkmark$ & Fisioterapis & Pasien \\
\hline 2 & $\begin{array}{l}\text { Mengelola jadwal } \\
\text { (menambah, mengubah, } \\
\text { dan menghapus) }\end{array}$ & $\checkmark$ & & \\
\hline 3 & $\begin{array}{l}\text { Mengelola fisioterapis } \\
\text { (menambah, mengubah, } \\
\text { dan menghapus) }\end{array}$ & $\checkmark$ & & \\
\hline 4 & Mencetak rekam medik & $\checkmark$ & & \\
\hline 5 & Melihat grafik pasien & $\checkmark$ & $\checkmark$ & \\
\hline 6 & Melihat rekam medik & & $\checkmark$ & \\
\hline 7 & Menambah rekam medik & & $\checkmark$ & \\
\hline 8 & Melihat jadwal & $\checkmark$ & $\checkmark$ & $\checkmark$ \\
\hline
\end{tabular}

Berdasarkan validasi yang dilakukan diperoleh hasil bahwa kebutuhan dan use case sistem yang dirancang telah sesuai dengan yang diinginkan oleh pengguna. Maka proses dapat dilanjutkan menuju tahap selanjutnya yaitu tahap elaboration.

\subsubsection{Tahap Elaboration}

Tahap elaboration merupakan kelanjutan dari tahap inception di mana pada tahapan analysis and design akan dilengkapi dengan menambahkan activity diagram, sequence diagram, class diagram dan desain database.

a. Analysis and Design, tahap elaboration yaitu perancangan activity diagram, sequence diagram, class diagram dan desain database.

1. Activity Diagram

Pada Gambar 6 merupakan proses menambah data pasien yang dilakukan oleh admin, dimana admin harus mengisi form data pasien yang kemudian akan divalidasi dan disimpan ke dalam database.

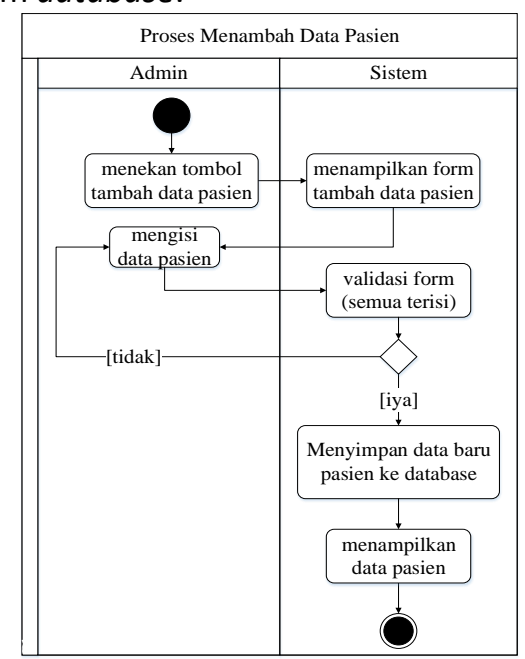

Gambar 6. Menambah data pasien

\section{Class Diagram}

Berdasarkan Gambar 7 dapat dilihat bahwa sistem dibangun menggunakan metode analisa beroriantasi objek dan menggunakan pola arsitektur MVC (Modeling Views Controllers), sehingga dilakukan perancangan kelas-kelas yang saling terhubung terdiri dari Models, Views, dan Controllers.

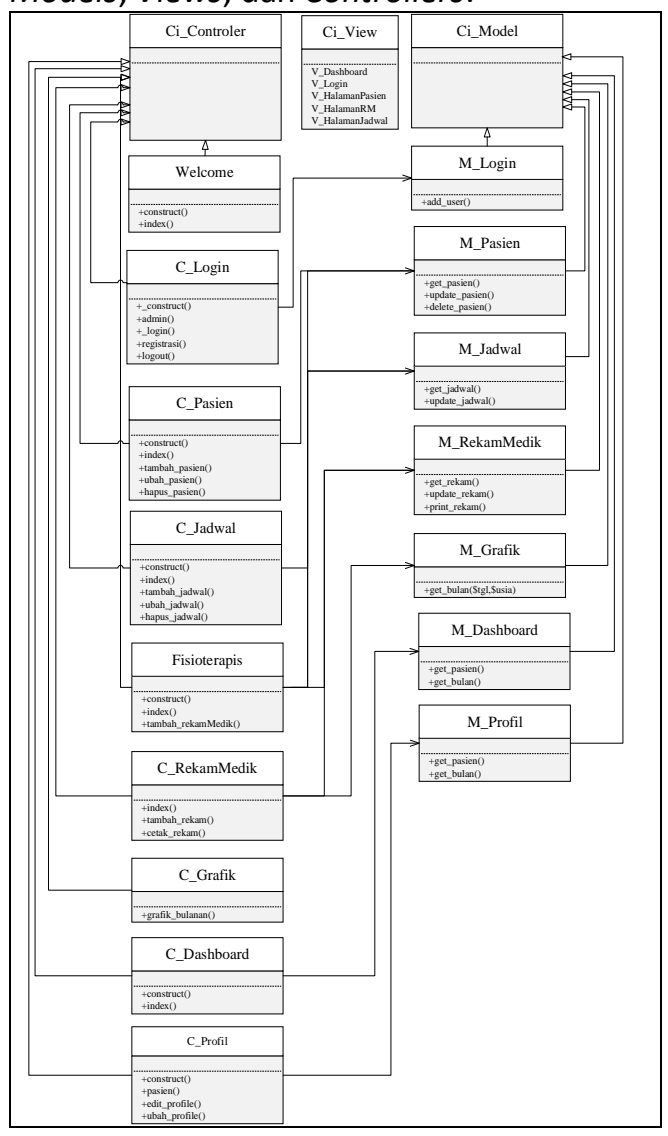

Gambar 7. Class diagram

\section{Sequence Diagram}

Pada Gambar 8 merupakan proses menambah pasien, dimulai ketika Admin mengisi data pasien baru pada halaman form tambah pasien. Kemudian hasil input data akan dikirimkan ke kelas C_Pasien menggunakan fungsi tambah_pasien(). Selanjutkan data tersebut akan ditambahkan ke dalam database menggunakan fungsi get_pasien() pada kelas M_Pasien. Jika berhasil ditambahkan, maka Admin diarahkan menuju halaman data pasien 


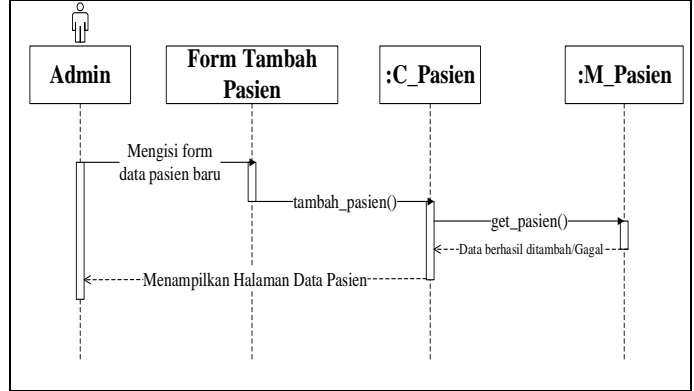

Gambar 8. Sequence diagram tambah data pasien.

4. Desain Database (ERD)

Desain database sistem yang akan dibangun dapat dilihat pada Gambar 9, dimana terdapat 8 tabel yaitu tabel admin, tabel admin_role, tabel fisioterapis, tabel gejala, tabel gejala_pasien, tabel jadwal, tabel pasien dan tabel rekammedik.

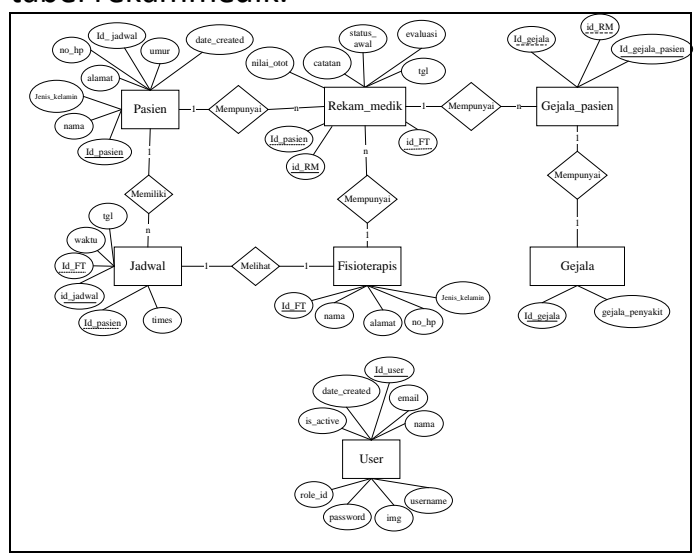

Gambar 9. ERD sistem

5. Implementasi

Pada implementasi tahapan elaboration dilakukan perancangan interface sistem seperti pada Gambar 10 yaitu tampilan form tambah pasien untuk menambah data pasien baru.

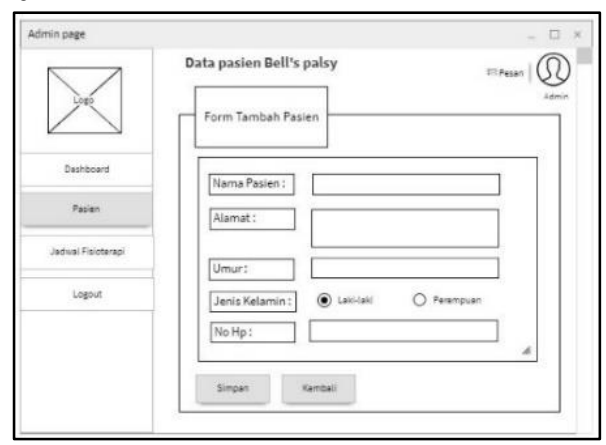

Gambar 10. Form tambah data pasien

\section{Test Elaboration}

Test elaboration merupakan tahapan pengujian fitur yang telah dirancang pada use case diagram dengan implementasi desain interface sistem, pengujian dilakakuan berdasarkan keinginan apakah sudah sesuai atau tidak.

TABEL IV. KeBUtuhan FUngSiOANAL SISTEM

\begin{tabular}{|c|c|c|c|c|}
\hline \multirow[b]{2}{*}{ No } & \multirow[b]{2}{*}{ Pengguna } & \multirow[b]{2}{*}{ Fitur } & \multicolumn{2}{|c|}{ Validasi } \\
\hline & & & Setuju & $\begin{array}{l}\text { Tidak } \\
\text { Setuju }\end{array}$ \\
\hline \multirow[t]{9}{*}{1} & \multirow[t]{9}{*}{ Admin } & Menambah data pasien & $\checkmark$ & \\
\hline & & Mengubah data pasien & $\checkmark$ & \\
\hline & & Menghapus data pasien & $\checkmark$ & \\
\hline & & Menambah jadwal & $\checkmark$ & \\
\hline & & Mengubah jadwal & $\checkmark$ & \\
\hline & & Menghapus jadwal & $\checkmark$ & \\
\hline & & Mencetak rekam medik & $\checkmark$ & \\
\hline & & Melihat grafik pasien & $\checkmark$ & \\
\hline & & Melihat jadwal & $\checkmark$ & \\
\hline \multirow[t]{4}{*}{2} & \multirow[t]{4}{*}{ Fisioterapis } & Melihat grafik pasien & $\checkmark$ & \\
\hline & & Melihat rekam medik & $\checkmark$ & \\
\hline & & $\begin{array}{l}\text { Menambah rekam } \\
\text { medik }\end{array}$ & $\checkmark$ & \\
\hline & & Melihat jadwal & $\checkmark$ & \\
\hline 3 & Pasien & Melihat jadwal & $\checkmark$ & \\
\hline
\end{tabular}

\section{Hasil dan Pembahasan}

Penerapan metode RUP pada pengembangan sistem dari tahapan RUP sebagai berikut.

\subsection{Tahap Construction}

Pada tahap contruction dilakukan dua proses yaitu implementation dan test, dikarenakan pada tahap sebelumnya yaitu elaboration sudah selesai.

\subsubsection{Implementation}

a. Database, pada tahapan pengembangan sistem informasi konsultasi dan penjadwalan penyakit Bell's palsy, terdapat 8 tabel yang digunakan seperti pada Gambar 11.

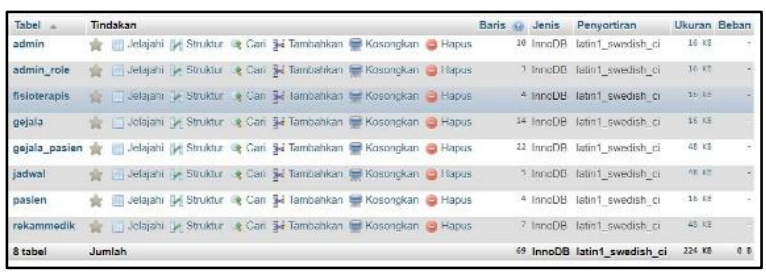

Gambar 11. Tabel database bell's palsy.

b. Project, pengembangan sistem dengan framework codeigniter dilakukan dengan menggunakan konsep MVC yaitu Models, Views dan Controllers. 


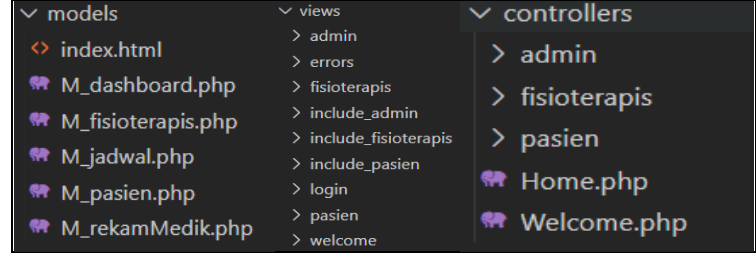

Gambar 12. MVC pada sistem.

Menghasilkan model M_dashboard, M_fisioterapis, M_jadwal, M_pasien, M_rekamMedik, kemudian untuk controler menghasilkan Home, Welcome, folder admin, folder fisioterapis, dan folder pasien. Sedangkan untuk views menghasilkan folder admin, folder fisioterapis, folder pasien, include_admin, inlcude_fisioterapis, folder login, folder welcome, inlude_pasien.

c. Interface, Pada Gambar 13 dan Gambar 14 merupakan beberapa tampilan halaman pada sistem untuk mengetahui informasi seputar penyakit Ball's palsy dan melakukan login.

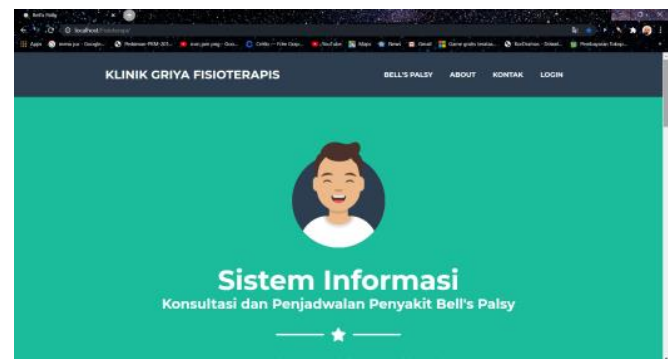

Gambar 13. Tampilan halaman awal

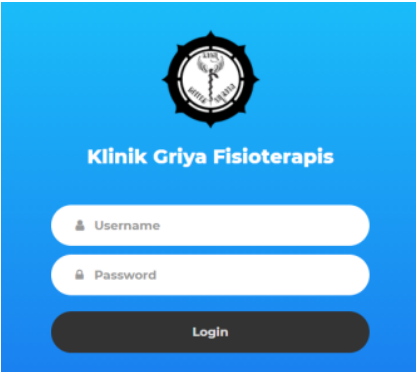

Gambar 14. Tampilan login.

d. Test Construction, pada tahap construction dilakukan pengujian fitur sistem dengan menggunakan black box testing untuk pengujian functional suitability, dimana pengujian suitability dibagi menjadi tiga bagian yaitu functional completeness, functional correctness, dan functional appropriateness. Pengujian black box testing yang dilakukan oleh 5 orang penguji yang terdiri dari 4 orang mahasiswa program studi
Teknik Informatika, Universitas Mataram dan seorang fisioterapis pada Klinik Griya Fisioterapis:

\section{Functional Completeness}

Pada pengujian functional completeness terdapat 22 fitur yang di uji untuk admin dan juga pasien yaitu seperti yang terlihat pada Tabel V.

TABEl V. PEnguJian functional COMPLETENESS

\begin{tabular}{|c|c|c|c|c|}
\hline \multirow{2}{*}{ No } & \multirow{2}{*}{ Fungsi } & \multirow{2}{*}{$\begin{array}{l}\text { Hasil yang } \\
\text { diharapkan }\end{array}$} & \multicolumn{2}{|c|}{ Hasil pengujian } \\
\hline & & & Sesuai & Tidak \\
\hline \multicolumn{5}{|c|}{ Admin } \\
\hline 1 & $\begin{array}{l}\text { Login } \\
\text { sebagai } \\
\text { admin }\end{array}$ & $\begin{array}{l}\text { Fungsi login } \\
\text { sebagai admin } \\
\text { sudah berjalan } \\
\text { dengan benar }\end{array}$ & $\begin{array}{c}5 \\
\text { responden }\end{array}$ & 0 \\
\hline 2 & $\begin{array}{l}\text { Menambah } \\
\text { data pasien }\end{array}$ & $\begin{array}{l}\text { Fungsi menambah } \\
\text { data pasien sudah } \\
\text { berjalan dengan } \\
\text { benar }\end{array}$ & $\begin{array}{c}5 \\
\text { responden }\end{array}$ & 0 \\
\hline 3 & $\begin{array}{l}\text { Mengubah } \\
\text { data pasien }\end{array}$ & $\begin{array}{l}\text { Fungsi mengubah } \\
\text { data pasien sudah } \\
\text { berjalan dengan } \\
\text { benar }\end{array}$ & $\begin{array}{c}5 \\
\text { responden }\end{array}$ & 0 \\
\hline 4 & $\begin{array}{l}\text { Menghapus } \\
\text { data pasien }\end{array}$ & $\begin{array}{l}\text { Fungsi menghapus } \\
\text { data pasien sudah } \\
\text { berjalan dengan } \\
\text { benar }\end{array}$ & $\begin{array}{c}5 \\
\text { responden }\end{array}$ & 0 \\
\hline 5 & $\begin{array}{l}\text { Mencetak } \\
\text { rekam } \\
\text { medik }\end{array}$ & $\begin{array}{l}\text { Fungsi mencetak } \\
\text { data rekam medik } \\
\text { sudah berjalan } \\
\text { dengan benar }\end{array}$ & $\begin{array}{c}5 \\
\text { responden }\end{array}$ & 0 \\
\hline 6 & $\begin{array}{l}\text { Melihat } \\
\text { grafik pasien }\end{array}$ & $\begin{array}{l}\text { Fungsi melihat data } \\
\text { grafik pasien sudah } \\
\text { berjalan dengan } \\
\text { benar }\end{array}$ & $\begin{array}{c}5 \\
\text { responden }\end{array}$ & 0 \\
\hline 7 & $\begin{array}{l}\text { Menambah } \\
\text { jadwal } \\
\text { fisioterapi }\end{array}$ & $\begin{array}{l}\text { Fungsi menambah } \\
\text { jadwal fisioterapi } \\
\text { sudah berjalan } \\
\text { dengan benar }\end{array}$ & $\begin{array}{c}5 \\
\text { responden }\end{array}$ & 0 \\
\hline 8 & $\begin{array}{l}\text { Mengubah } \\
\text { jadwal } \\
\text { fisioterapi }\end{array}$ & $\begin{array}{l}\text { Fungsi mengubah } \\
\text { jadwal fisioterapi } \\
\text { sudah berjalan } \\
\text { dengan benar }\end{array}$ & $\begin{array}{c}5 \\
\text { responden }\end{array}$ & 0 \\
\hline 9 & $\begin{array}{l}\text { Menghapus } \\
\text { jadwal } \\
\text { fisioterapi }\end{array}$ & $\begin{array}{l}\text { Fungsi menghapus } \\
\text { jadwal fisioterapi } \\
\text { sudah berjalan } \\
\text { dengan benar }\end{array}$ & $\begin{array}{c}5 \\
\text { responden }\end{array}$ & 0 \\
\hline 10 & $\begin{array}{l}\text { Melihat } \\
\text { jadwal } \\
\text { fisioterapi }\end{array}$ & $\begin{array}{l}\text { Fungsi melihat } \\
\text { jadwal fisioterapi } \\
\text { sudah berjalan } \\
\text { dengan benar }\end{array}$ & $\begin{array}{c}5 \\
\text { responden }\end{array}$ & 0 \\
\hline 11 & $\begin{array}{l}\text { Menambah } \\
\text { fisioterapis }\end{array}$ & $\begin{array}{l}\text { Fungsi menambah } \\
\text { data fisioterapis } \\
\text { pada sistem sudah } \\
\text { berjalan dengan } \\
\text { benar }\end{array}$ & $\begin{array}{c}5 \\
\text { responden }\end{array}$ & 0 \\
\hline 12 & $\begin{array}{l}\text { Mengubah } \\
\text { fisioterapis }\end{array}$ & $\begin{array}{l}\text { Fungsi mengubah } \\
\text { data fisioterapis } \\
\text { pada sistem sudah } \\
\text { berjalan dengan } \\
\text { benar }\end{array}$ & $\begin{array}{c}5 \\
\text { responden }\end{array}$ & 0 \\
\hline 13 & $\begin{array}{l}\text { Menghapus } \\
\text { fisioterapis }\end{array}$ & $\begin{array}{l}\text { Fungsi menghapus } \\
\text { data fisioterapis }\end{array}$ & $\begin{array}{c}5 \\
\text { responden }\end{array}$ & 0 \\
\hline
\end{tabular}




\begin{tabular}{|c|c|c|c|c|}
\hline & & $\begin{array}{l}\text { pada sistem sudah } \\
\text { berjalan dengan } \\
\text { benar }\end{array}$ & & \\
\hline \multicolumn{5}{|c|}{ Fisioterapis } \\
\hline 14 & $\begin{array}{l}\text { Login } \\
\text { sebagai } \\
\text { Fisioterapis }\end{array}$ & \begin{tabular}{|l} 
Fungsi login \\
sebagai fisioterapis \\
pada sistem sudah \\
berjalan dengan \\
benar
\end{tabular} & $\begin{array}{c}5 \\
\text { responden }\end{array}$ & 0 \\
\hline 15 & $\begin{array}{l}\text { Mengubah } \\
\text { data pribadi }\end{array}$ & $\begin{array}{l}\text { Fungsi mengubah } \\
\text { data pribadi sudah } \\
\text { berjalan dengan } \\
\text { benar }\end{array}$ & $\begin{array}{c}5 \\
\text { responden }\end{array}$ & 0 \\
\hline 16 & $\begin{array}{l}\text { Melihat } \\
\text { grafik pasien }\end{array}$ & $\begin{array}{l}\text { Fungsi melihat data } \\
\text { grafik pasien sudah } \\
\text { berjalan dengan } \\
\text { benar }\end{array}$ & $\begin{array}{c}5 \\
\text { responden }\end{array}$ & 0 \\
\hline 17 & $\begin{array}{l}\text { Melihat } \\
\text { rekam } \\
\text { medik }\end{array}$ & $\begin{array}{l}\text { Fungsi melihat data } \\
\text { rekam medik sudah } \\
\text { berjalan dengan } \\
\text { benar }\end{array}$ & $\begin{array}{c}5 \\
\text { responden }\end{array}$ & 0 \\
\hline 18 & $\begin{array}{l}\text { Melihat } \\
\text { jadwal } \\
\text { fisioterapi }\end{array}$ & $\begin{array}{l}\text { Fungsi melihat } \\
\text { jadwal fisioterapis } \\
\text { pada sistem sudah } \\
\text { berjalan dengan } \\
\text { benar }\end{array}$ & $\begin{array}{c}5 \\
\text { responden }\end{array}$ & 0 \\
\hline 19 & $\begin{array}{l}\text { Menambah } \\
\text { rekam } \\
\text { medik }\end{array}$ & $\begin{array}{l}\text { Fungsi menambah } \\
\text { data rekam medik } \\
\text { sudah berjalan } \\
\text { dengan benar }\end{array}$ & $\begin{array}{c}5 \\
\text { responden }\end{array}$ & 0 \\
\hline \multicolumn{5}{|c|}{ Pasien } \\
\hline 20 & $\begin{array}{l}\text { Login } \\
\text { sebagai } \\
\text { pasien }\end{array}$ & $\begin{array}{l}\text { Fungsi login } \\
\text { sebagai pasien } \\
\text { sudah berjalan } \\
\text { dengan benar }\end{array}$ & $\begin{array}{c}5 \\
\text { responden }\end{array}$ & 0 \\
\hline 21 & $\begin{array}{l}\text { Mengubah } \\
\text { data pribadi }\end{array}$ & $\begin{array}{l}\text { Fungsi mengubah } \\
\text { data pribadi sudah } \\
\text { berjalan dengan } \\
\text { benar }\end{array}$ & $\begin{array}{c}5 \\
\text { responden }\end{array}$ & 0 \\
\hline 22 & $\begin{array}{l}\text { Melihat } \\
\text { jadwal } \\
\text { fisioterapi }\end{array}$ & $\begin{array}{l}\text { Fungsi melihat data } \\
\text { jadwal fisioterapi } \\
\text { sudah berjalan } \\
\text { dengan benar }\end{array}$ & $\begin{array}{c}5 \\
\text { responden }\end{array}$ & 0 \\
\hline
\end{tabular}

Berdasarkan pengujian yang dilakukan oleh 5 orang pengguna diperoleh hasil seperti pada rumus berikut.

$\mathrm{P}=$ jumlah pernyataan $\mathrm{x}$ jumlah responden

$$
=22 \times 5=110
$$

$\mathrm{I}=$ jumlah nilai $\mathrm{x}$ jumlah pengujian

$$
=22 \times 5=110
$$

Sehingga,

$$
\mathrm{X}=\frac{I}{P}=\frac{110}{110}=1
$$

Sebuah sistem dikatakan baik jika nilai $X$ mendekati 1 , dan pada pengujian yang dilakukan terahadap functional completeness sistem didapatkan hasil 1, jadi dapat disimpulkan bahwa fitur sistem sudah berjalan dengan baik.

\section{Functional Correctness}

Pada pengujian functional correctness terdapat 6 fitur yang diuji untuk fitur secara umum, admin, dan fisioterapis seperti yang terlihat Tabel VI.

\begin{tabular}{|c|c|c|c|c|}
\hline \multirow{2}{*}{ No } & \multirow{2}{*}{ Fungsi } & \multirow{2}{*}{ Hasil yang diharapkan } & \multicolumn{2}{|c|}{ Hasil pengujian } \\
\hline & & & Sesuai & Tidak \\
\hline \multicolumn{5}{|c|}{ Umum } \\
\hline 1 & \begin{tabular}{|l} 
Identifikasi \\
username \\
dan \\
password
\end{tabular} & $\begin{array}{l}\text { Proses login ke sistem } \\
\text { sesuai dengan jenis } \\
\text { user sudah berjalan } \\
\text { degan benar }\end{array}$ & $\begin{array}{c}5 \\
\text { responden }\end{array}$ & 0 \\
\hline 2 & $\begin{array}{l}\text { Menampilka } \\
\text { n data } \\
\text { jadwal } \\
\text { fisioterapis } \\
\text { berdasarkan } \\
\text { kata kunci }\end{array}$ & $\begin{array}{l}\text { Proses menampilkan } \\
\text { data jadwal fisioterapi } \\
\text { pada sistem } \\
\text { berdasarkan kata } \\
\text { kunci tertentu sudah } \\
\text { berjalan dengan benar }\end{array}$ & $\begin{array}{c}5 \\
\text { responden }\end{array}$ & 0 \\
\hline \multicolumn{5}{|c|}{ Admin } \\
\hline 3 & $\begin{array}{l}\text { Perhitungan } \\
\text { jumlah data } \\
\text { pasien dan } \\
\text { fisioterapis } \\
\text { pada } \\
\text { dashboard }\end{array}$ & $\begin{array}{l}\text { Proses menampilkan } \\
\text { data pasien dan } \\
\text { fisioterapis sesuai } \\
\text { dengan jenis kelamin, } \\
\text { baik dalam data grafik } \\
\text { pada dahboard sistem } \\
\text { sudah berjalan } \\
\text { dengan benar }\end{array}$ & $\begin{array}{c}5 \\
\text { responden }\end{array}$ & 0 \\
\hline 4 & $\begin{array}{l}\text { Menampilka } \\
\text { n data } \\
\text { pasien dan } \\
\text { fisioterapis } \\
\text { berdasarkan } \\
\text { kata kunci }\end{array}$ & $\begin{array}{l}\text { Proses menampilkan } \\
\text { data pasien dan } \\
\text { fisioterapis pada } \\
\text { sistem berdasarkan } \\
\text { kata kunci tertentu } \\
\text { sudah berjalan dengan } \\
\text { benar }\end{array}$ & $\begin{array}{c}5 \\
\text { responden }\end{array}$ & 0 \\
\hline \multicolumn{5}{|c|}{ Fisioterapis } \\
\hline 5 & \begin{tabular}{|l|} 
Menampilka \\
n data hasil \\
rekam \\
medik \\
berdasarkan \\
kata kunci \\
\end{tabular} & \begin{tabular}{|lrr} 
Proses & menampilkan \\
data & pasien & hasil \\
rekam & & medik \\
berdasarkan & kata \\
kunci & tertentu & sudah \\
berjalan dengan & benar \\
\end{tabular} & $\begin{array}{c}5 \\
\text { responden }\end{array}$ & 0 \\
\hline 6 & $\begin{array}{l}\text { Menampilka } \\
\text { n riwayat } \\
\text { data rekam } \\
\text { medik } \\
\text { pasien } \\
\text { berdasarkan } \\
\text { pencarian }\end{array}$ & $\begin{array}{lr}\text { Proses menampilkan } \\
\text { riwayat data } & \text { rekam } \\
\text { medik } & \text { pasien } \\
\text { berdasarkan r kata } \\
\text { kunci tertentu } & \text { sudah } \\
\text { berjalan dengan benar }\end{array}$ & $\begin{array}{c}5 \\
\text { responden }\end{array}$ & 0 \\
\hline
\end{tabular}

TABEL VI. Pengujian functional CORRECTNESS

Berdasarkan pengujian yang dilakukan oleh 5 orang pengguna diperoleh hasil seperti pada rumus berikut.

$\mathrm{P}=$ jumlah pernyataan $\mathrm{x}$ jumlah responden

$$
=6 \times 5=30
$$

$\mathrm{I}=$ jumlah nilai $\mathrm{x}$ jumlah pengujian

$$
=6 \times 5=30
$$

Sehingga,

$$
\mathrm{X}=\frac{I}{P}=\frac{30}{30}=1
$$

Sebuah sistem dikatakan baik jika nilai $X$ mendekati 1, dan pada pengujian yang dilakukan terahadap functional completeness sistem didapatkan hasil 1, jadi dapat 
disimpulkan bahwa fitur sistem sudah berjalan dengan baik.

3. Fuctional Appropriateness

Pada pengujian functional appropriateness terdapat 1 fitur yang diuji seperti yang terlihat Tabel VII.

TABEL VII. PENGUJIAN Functional APPROPIATENESS

\begin{tabular}{|c|c|c|c|c|}
\hline \multirow{2}{*}{ No } & Fungsi & \multicolumn{1}{c|}{$\begin{array}{c}\text { Hasil yang } \\
\text { diharapkan }\end{array}$} & \multicolumn{2}{|c|}{ Hasil pengujian } \\
\cline { 5 - 5 } 1 & \multicolumn{3}{|c|}{ Admin } & Tidak \\
\hline \multirow{3}{*}{1} & $\begin{array}{l}\text { Mencetak } \\
\text { data rekam } \\
\text { medik }\end{array}$ & $\begin{array}{l}\text { Fungsi mencetak } \\
\text { data rekam } \\
\text { medik pasien } \\
\text { berdasarkan data } \\
\text { pasien sudah } \\
\text { berjalan dengan } \\
\text { benar }\end{array}$ & $\begin{array}{c}5 \\
\text { responden }\end{array}$ & 0 \\
\hline
\end{tabular}

Berdasarkan pengujian yang dilakukan oleh seorang pengguna diperoleh hasil seperti pada rumus berikut.

$\mathrm{P}=$ jumlah pernyataan $\mathrm{x}$ jumlah responden

$$
=1 \times 5=5
$$

$\mathrm{I}=$ jumlah nilai $\mathrm{x}$ jumlah pengujian

$$
=1 \times 5=5
$$

Sehingga,

$$
\mathrm{X}=\frac{I}{P}=\frac{5}{5}=1
$$

Sebuah sistem dikatakan baik jika nilai $X$ mendekati 1, dan pada pengujian yang dilakukan terahadap functional completeness sistem didapatkan hasil 1, jadi dapat disimpulkan bahwa fitur sistem sudah berjalan dengan baik.

\subsection{TAHAP TRANSITION}

Pada tahapan transition dilakukan testing usibility sistem untuk mengetahui kesesuian sistem dengan kebutuhan pengguna. Proses pengujian dilakukan oleh dua pihak, yaitu dari pihak klinik sebagai fisioterapis, dan dari pihak masyarakat umum sebagai pasien.

1. Fisioterapis

Pengujian untuk pihak klinik dilakukan oleh seorang fisioterapis pada Klinik Griya Fisioterapis

\begin{tabular}{|c|c|c|c|c|c|c|c|c|c|c|c|c|c|c|c|}
\hline \multirow{3}{*}{$\begin{array}{c}\text { Nomor } \\
\text { Responden }\end{array}$} & \multicolumn{13}{|c|}{ Pernyataan } & \multirow{3}{*}{$\begin{array}{l}\text { Total } \\
\text { Nilai }\end{array}$} & \multirow{3}{*}{$\begin{array}{c}\text { Nilai } \\
\text { Maksimal }\end{array}$} \\
\hline & \multicolumn{4}{|c|}{ Usefulness } & \multicolumn{5}{|c|}{ Ease of use } & \multicolumn{2}{|c|}{$\begin{array}{l}\text { Ease of } \\
\text { learning }\end{array}$} & \multicolumn{2}{|c|}{ Satisfaction } & & \\
\hline & 1 & 2 & 3 & 4 & 5 & 6 & 7 & 8 & 9 & 10 & 11 & 12 & 13 & & \\
\hline 1 & 5 & 5 & 5 & 5 & 5 & 4 & 4 & 5 & 4 & 4 & 4 & 5 & 5 & 60 & 65 \\
\hline
\end{tabular}
menghasilkan pengujian seperti pada Tabel VIII.

TABEL VIII. HASIL PENGUJIAN DARI PIHAK KLINIK

Berdasarkan hasil diatas dapat diperoleh total nilai sebesar 60. Hasil pengujian usability dapat diperoleh dengan rumus sebagai berikut.

$$
\text { P Skor }=\frac{60}{65} x 100 \%=92,30 \%
$$

Dari hasil perhitungan diperoleh persentase pengujian usability sebesar $92,30 \%$, sehingga dapat disimpulkan bahwa ada kecendrungan Sistem Informasi Konsultasi dan Penjadwalan Fisioterapi Penyakit Bell's Palsy dinyatakan relatif layak dikarenakan pengujian dilakukan pada seorang fisioterapis. Hasil pengujian akurasi pengujian usability dapat dilihat pada tautan berikut: http://bit.ly/PengujianUsabilityFisio

2. Pasien

Pengujian dari pihak pasien dilakukan oleh 30 orang yang diambil secara acak dari berbagai bidang

\begin{tabular}{|c|c|c|c|c|c|c|c|c|c|c|c|}
\hline \multicolumn{12}{|c|}{ UMUM } \\
\hline \multirow{3}{*}{$\begin{array}{c}\text { No } \\
\text { Responden }\end{array}$} & \multicolumn{9}{|c|}{ Pernyataan } & \multirow{3}{*}{$\begin{array}{l}\text { Total } \\
\text { Nilai }\end{array}$} & \multirow{3}{*}{$\begin{array}{c}\text { Nilai } \\
\text { Maksima }\end{array}$} \\
\hline & \multicolumn{2}{|c|}{ Usefulness } & \multicolumn{4}{|c|}{ Ease of use } & \multicolumn{2}{|c|}{$\begin{array}{l}\text { Ease of } \\
\text { learning }\end{array}$} & \multirow{2}{*}{$\begin{array}{c}\text { Satisfaction } \\
9\end{array}$} & & \\
\hline & 1 & 2 & 3 & 4 & 5 & 6 & 7 & 8 & & & \\
\hline 1 & 5 & 4 & 5 & 5 & 5 & 4 & 5 & 5 & 5 & 43 & 45 \\
\hline 2 & 5 & 5 & 4 & 4 & 5 & 4 & 4 & 4 & 5 & 40 & 45 \\
\hline 3 & 4 & 5 & 5 & 5 & 3 & 4 & 4 & 4 & 4 & 38 & 45 \\
\hline 4 & 5 & 4 & 4 & 4 & 5 & 4 & 4 & 5 & 5 & 40 & 45 \\
\hline 5 & 4 & 5 & 4 & 4 & 5 & 4 & 5 & 5 & 4 & 40 & 45 \\
\hline 6 & 5 & 4 & 4 & 5 & 4 & 4 & 4 & 4 & 4 & 38 & 45 \\
\hline 7 & 5 & 5 & 4 & 4 & 4 & 4 & 4 & 4 & 4 & 38 & 45 \\
\hline 8 & 5 & 5 & 4 & 4 & 5 & 4 & 4 & 4 & 5 & 40 & 45 \\
\hline 9 & 4 & 5 & 5 & 4 & 4 & 4 & 4 & 4 & 4 & 38 & 45 \\
\hline 10 & 5 & 4 & 5 & 4 & 5 & 4 & 4 & 4 & 5 & 40 & 45 \\
\hline 11 & 4 & 5 & 4 & 4 & 4 & 4 & 4 & 4 & 4 & 37 & 45 \\
\hline 12 & 4 & 4 & 4 & 5 & 5 & 4 & 4 & 4 & 4 & 38 & 45 \\
\hline 13 & 4 & 4 & 5 & 4 & 5 & 4 & 4 & 4 & 5 & 39 & 45 \\
\hline 14 & 4 & 5 & 4 & 5 & 5 & 3 & 5 & 4 & 5 & 40 & 45 \\
\hline 15 & 4 & 4 & 5 & 5 & 5 & 5 & 5 & 5 & 4 & 42 & 45 \\
\hline 16 & 5 & 5 & 4 & 4 & 4 & 3 & 4 & 4 & 5 & 38 & 45 \\
\hline 17 & 4 & 5 & 4 & 4 & 4 & 4 & 3 & 4 & 4 & 36 & 45 \\
\hline 18 & 4 & 4 & 5 & 4 & 4 & 4 & 4 & 4 & 3 & 36 & 45 \\
\hline 19 & 4 & 4 & 5 & 4 & 5 & 5 & 5 & 5 & 4 & 41 & 45 \\
\hline 20 & 5 & 4 & 5 & 5 & 5 & 4 & 4 & 4 & 3 & 39 & 45 \\
\hline 21 & 4 & 4 & 5 & 5 & 5 & 5 & 5 & 5 & 5 & 43 & 45 \\
\hline 22 & 4 & 4 & 4 & 4 & 4 & 3 & 4 & 4 & 5 & 36 & 45 \\
\hline 23 & 5 & 5 & 4 & 4 & 4 & 3 & 5 & 4 & 4 & 38 & 45 \\
\hline 24 & 5 & 5 & 4 & 4 & 4 & 4 & 3 & 3 & 4 & 36 & 45 \\
\hline 25 & 4 & 4 & 5 & 5 & 4 & 4 & 5 & 5 & 5 & 41 & 45 \\
\hline 26 & 4 & 5 & 3 & 5 & 4 & 4 & 5 & 4 & 4 & 38 & 45 \\
\hline 27 & 5 & 5 & 4 & 4 & 5 & 4 & 4 & 4 & 3 & 38 & 45 \\
\hline 28 & 5 & 5 & 4 & 4 & 4 & 5 & 5 & 5 & 4 & 41 & 45 \\
\hline 29 & 5 & 5 & 5 & 5 & 4 & 4 & 5 & 4 & 5 & 42 & 45 \\
\hline 30 & 5 & 4 & 5 & 5 & 4 & 4 & 5 & 5 & 4 & 41 & 45 \\
\hline & & & & Tota & Nilai & & & & & 1175 & 1350 \\
\hline
\end{tabular}
pekerjaan, menghasilkan pengujian seperti pada Tabel IX.

TABEL IX. HASIL PENGUJIAN DARI MASYARAKAT

Berdasarkan hasil diatas dapat diperoleh total nilai sebesar 1175 . Hasil pengujian usability dapat diperoleh dengan rumus sebagai berikut.

$$
\text { P Skor }=\frac{1175}{1350} x 100 \%=87,03 \%
$$

Dari hasil perhitungan diperoleh persentase pengujian usability sebesar $87,03 \%$. Sehingga dapat disimpulkan bahwa Sistem Informasi Konsultasi dan Penjadwalan Fisioterapi Penyakit Bell's Palsy memenuhi standar usability, yang mengacu pada tabel 
I yaitu tabel kriteria interpretasi skor dan dinyatakan sangat layak. Hasil pengujian akurasi pengujian usability dapat dilihat pada tautan berikut: http://bit.ly/PengujianUsability_MasyarakatUmum

\section{KeSIMPULAN}

Berdasarkan penelitian yang telah dilakukan, dapat ditarik beberapa kesimpulan yaitu:

1. Pembuatan Sistem Informasi Konsultasi dan Penjadwalan Fisioterapis Penyakit Bell's Palsy ini dapat digunakan untuk memudahkan fisioterapis dalam melakukan diagnosis awal penyakit Bell's Palsy, melakukan penjadwalan pasien penyakit Bell's Palsy, dan melakukan penyimpanan data rekam medik pasien Bell's Palsy pada Klinik Griya Fisioterapis.

2. Pengujian terhadap sistem yang dibangun menggunakan metode RUP dilakukan dengan menggunakan pengujian suitability (black box testing) dan mengguanakan kuisioner (usability). Pada pengujian black box testing diperoleh hasil sebesar 1 yang berarti semua fitur sudah berjalan dengan benar. Pada pengujian usability diperoleh hasil sebesar $92,30 \%$ dinyatakan relatif layak dikarenakan pengujian dilakukan pada seorang fisioterapis, dan $87,03 \%$ yang dilakukan dengan 30 responden memenuhi standar usability yang mengacu pada tabel I yaitu tabel kriteria interpretasi skor atau dinyatakan "Sangat Layak", sehingga metode RUP merupakan metode yang baik untuk pengembangan sistem.

\section{UCAPAN TERIMA KASIH}

Ucapan terima kasih penulis berikan kepada Klinik Griya Fisioterapis yang telah memberikan ruang kepada penulis untuk melakukan penelitian khususnya kepada R. Arif Trianto C, S.ST.FT., S.Th.I., NMTCP-SM selaku Fisioterapis yang telah meluangkan waktu untuk memberikan ilmunya sampai penelitian ini selesai. Dan kepada seluruh pihak yang telah membantu penulis dalam menyelesaikan penelitian ini yang tidak dapat penulis sebutkan satu per satu.

\section{DAFTAR PUSTAKA}

[1] H. H. Bin Abdullah, "Karakteristik Pasien Bell's Palsy Di Rumah Sakit Umum Pusat Dr. Wahidin
Sudirohusodo Pada Tahun 2016," J. Chem. Inf. Model., vol. 53, no. 9, pp. 1689-1699, 2017.

[2] P. S. Hasibuan and M. I. Batubara, "Penerapan Metode Dempster Shafer Dalam Mendiagnosa Penyakit Faringitis," Muhammad Syaril, Nelly Astuti Hasibuan, Pristiwanto, vol. 3, no. 1, pp. 101-105, 2016.

[3] O. M. Adam, "Bell' s Palsy," Library (Lond)., vol. 2071, no. 1, pp. 1323-1331, 2019.

[4] F. Mubarok, H. Harliana, and I. Hadijah, "Perbandingan Antara Metode RUP dan Prototype Dalam Aplikasi Penerimaan Siswa Baru Berbasis Web," Creat. Inf. Technol. J., vol. 2, no. 2, p. 114, 2015.

[5] M. Destiningrum and Q. J. Adrian, "Sistem Informasi Penjadwalan Dokter Berbassis Web Dengan Menggunakan Framework Codeigniter (Studi Kasus: Rumah Sakit Yukum Medical Centre)," J. Teknoinfo, vol. 11, no. 2, p. 30, 2017.

[6] W. R. Amanda, "Penatalaksanaan Fisioterapi Untuk Meningkatkan Kekuatan Otot Dan Mengembalikan Kesimetrisan Wajah Pada Kasus Bell's Palsy Sinistra Di Rsud Dr. Soeselo Slawi," Fisioter. Fak. IImu Kesehat., 2019.

[7] R. Perwitasari, R. Afwani, and S. E. Anjarwani, "Penerapan Metode Rational Unified Process (RUP) Dalam Pengembangan Sistem Informasi Medical Check Up Pada Citra Medical Centre," J. Teknol. Informasi, Komputer, dan Apl. (JTIKA ), vol. 2, no. 1, pp. 76-88, 2020.

[8] Normah, "Sistem Informasi Konsultasi Kesehatan Berbasis Website," J. Sist. Inf. STMIK Antar Bangsa, vol. 5, no. 2, pp. 196-200, 2016.

[9] N. MILLAH, "Rancang Bangun Sistem Informasi Konsultasi Medis Berbasis Website," Ranc. BANGUN Sist. Inf. Konsult. MEDIS Berbas. WEBSITE Pandu, vol. 0, no. 2015, pp. 55-60, 2019.

[10] Y. Sugiarti, "Analisis \& Perancangan UML (Unified Modeling Language) Generated VB.6," Graha IImu, pp. 30-45, 2013.

[11] A. Triwahyuni and N. Saputra, "Architecture E-Mall Using Rup (Rational Unifed Process) Methods," CoglTo Smart J., vol. 1, no. 1, p. 1, 2015.

[12] H. Saputro, "Modul Pembelajaran Praktek Basis Data (MySQL)," Modul Pembelajaran Prakt. Basis Data, pp. 1-34, 2016.

[13] D. M. Dipayana et al., "Rancang Bangun Sistem Informasi Geografis Berbasis Web dan Android Untuk Pemetaan Industri Kecil dan Menengah di Kota Mataram," vol. 2, no. 1, 2020. 